\title{
Genetic structure and diversity among individuals of Copaifera langsdorffii Desf. from Mato Grosso, Brazilian Amazon, using ISSR markers
}

\author{
Diversidade e estrutura genética entre indivíduos de Copaifera langsdorffii Desf. de Mato Grosso,
} Amazônia Brasileira, por meio de marcadores ISSR

Diversidad y estructura genética entre individuos de Copaifera langsdorffii Desf. de Mato Grosso, Amazonía Brasileira, utilizando marcadores ISSR

Received: 11/09/2021 | Reviewed: 11/24/2021 | Accept: 11/30/2021| Published: 12/11/2021

\author{
Daniele Paula Maltezo \\ ORCID: https://orcid.org/0000-0003-1712-7713 \\ Universidade do Estado de Mato Grosso, Brazil \\ E-mail: danielemaltezo@gmail.com \\ Julliane Dutra Medeiros \\ ORCID: https://orcid.org/0000-0002-1049-9410 \\ Universidade do Estado de Mato Grosso, Brazil \\ E-mail: jdutramedeiros@gmail.com \\ Ana Aparecida Bandini Rossi \\ ORCID: https://orcid.org/0000-0002-8318-5375 \\ Universidade do Estado de Mato Grosso, Brazil \\ E-mail: anabanrossi@gmail.com
}

\begin{abstract}
The Amazon is the largest tropical forest in the world and is home to around $20 \%$ of all the biodiversity on the planet, among the species present in the Amazon is Copaifera langsdorffii, exploited mainly for the extraction of oil-resin and wood, often in ways incorrect, which can cause the loss of genetic variability. The aim of this study was to evaluate the genetic structure and diversity among individuals of $C$. langsdorffii located in Mato Grosso, Brazil, using ISSR markers. We sampled leaves from 27 adult individuals of $C$. langsdorffii, whose total genomic DNA was extracted. A total of 12 ISSR primers were used for the molecular characterization of the individuals. A grouping analysis was performed using the unweighted pair group method, Bayesian analysis and characterized by the genetic diversity. The genetic diversity among and within the groups was demonstrated by the AMOVA. As a result, 106 fragments were amplified and $98.11 \%$ were polymorphic. The polymorphic information content of each primer ranged from 0.45 to 0.81 . The dendrogram showed the formation of 4 distinct groups. The greatest genetic variability is found within the groups and not between them. The percentage of polymorphism, genetic dissimilarity values and genetic diversity indexes indicate that there is high genetic variability among Copaifera langsdorffii individuals, suggesting that ISSR primers were efficient in detecting polymorphism in this species and that the individuals have potential for compose programs aimed at the preservation of the species and the ability to integrate germplasm banks.
\end{abstract}

Keywords: Biodiversity; Molecular characterization; Copaiba; Molecular marker; Genetic variability.

\begin{abstract}
Resumo
A Amazônia é a maior Floresta tropical do mundo e abriga cerca de $20 \%$ de toda a biodiversidade do planeta, dentre as espécies presentes na Amazônia está a Copaifera langsdorffii, explorada principalmente para extração de óleo-resina e madeira, muitas vezes de forma incorreta, o que pode ocasionar a perda de variabilidade genética. O objetivo deste trabalho foi avaliar a diversidade e estrutura genética entre indivíduos de $C$. langsdorffii localizada da Amazônia Mato-Grossense, por meio de marcadores ISSR. Foram amostradas folhas de 27 indivíduos adultos de $C$. langsdorffii, cujo DNA genômico total foi extraído. Foram utilizados 12 primers ISSR para caracterização molecular dos indivíduos. Foram realizadas análise de agrupamento, análise bayesiana, e caracterização da variabilidade genética. A diversidade genética entre e dentro dos grupos foi demonstrada a partir da AMOVA. Foram amplificados 106 fragmentos, sendo $98,11 \%$ polimórficos. O conteúdo de informação polimórfica de cada primer variou entre 0,45 e 0,81 . O dendrograma mostrou a formação de 4 grupos distintos. A maior variabilidade genética encontra-se dentro dos grupos e não entre eles. O percentual de polimorfismo, valores de dissimilaridade genética e índices de diversidade genética apontam que há alta variabilidade genética entre os indivíduos de Copaifera langsdorffii, sugerindo que os primers ISSR se mostraram eficientes na detecção de polimorfismo nesta
\end{abstract}


espécie e que os indivíduos apresentam potencial para compor programas que visem a preservação da espécie e capacidade de integrar bancos de germoplasma.

Palavras-chave: Biodiversidade; Caracterização molecular; Copaíba; Marcador molecular; Variabilidade genética.

\section{Resumen}

La Amazonía es el bosque tropical más grande del mundo y alberga alrededor del $20 \%$ de toda la biodiversidad del planeta, entre las especies presentes en la Amazonía se encuentra Copaifera langsdorffii, explotada principalmente para la extracción de aceite-resina y madera, a menudo de forma incorrecta, lo que puede provocar la pérdida de variabilidad genética. El objetivo fue evaluar la estructura y diversidad genética entre individuos de C. langsdorffii ubicados en la Amazonía (Mato Grosso, Brasil), utilizando marcadores ISSR. Muestreamos hojas de 27 individuos adultos de $C$. langsdorffii, cuyo ADN genómico total fue extraído. Se utilizaron doce cebadores ISSR para la caracterización molecular. Se realizó análisis de conglomerados, el análisis bayesiano y caracterización de la variabilidad genética. La diversidad genética entre y dentro de los grupos se demostró a partir del AMOVA. Se amplificaron 106 fragmentos, 98.11\% de los cuales eran polimórficos. El contenido de información polimórfica de cada cebador varió entre 0.45 y 0.81. El dendrograma mostró la formación de 4 grupos distintos. La mayor variabilidad genética se encuentra dentro de los grupos y no entre ellos. El porcentaje de polimorfismo, los valores de disimilitud genética y los índices de diversidad genética señalan que existe una alta variabilidad genética entre los individuos de Copaifera langsdorffii, lo que sugiere que los cebadores ISSR demostraron ser eficientes en la detección de polimorfismo en esta especie y que el los individuos tienen potencial para componer programas dirigidos a la preservación de la especie y la capacidad de integrar bancos de germoplasma.

Palabras clave: Biodiversidad; Caracterización molecular; Copaiba; Marcador molecular; Variabilidad genética.

\section{Introduction}

With approximately 6.7 million km2, the Amazon Rainforest is considered the largest tropical forest in the world, and $60 \%$ of its extension is in Brazilian territory (Ferreira et al., 2010). As such, it is home to about $20 \%$ of all biodiversity on the planet (Silva, 2018). Among the species present in the Amazon, the Copaifera langsdorffii Desf. (Copaíba) stands out and is widely distributed in Brazil (Lorenzi, 1992; Reis et al., 2016). It is exploited mainly for the extraction of its resinous oil, which is used in popular medicine as an anti-inflammatory and bactericide (Lisboa et al., 2018), and in industries: pharmacological, drug development; cosmetics: for the production of fixatives for fragrances, cosmetics and soaps; and in varnishes and solvents, for their production (Veiga \& Pinto, 2002). Copaiba oil also stands out as a raw material for the manufacture of soaps and soaps by small Family businessses, fostering regional trade (Sousa et al., 2016). And its wood, in the production of plywood (Lisboa et al., 2018).

Inadequate management of $C$. langsdorffii, as well as forest fragmentation, influence the genetic composition of populations. This also causes a decrease in the number of individuals, which in the long term can lead to an increase in inbreeding, a reduction in genetic variability and consequently the loss of the adaptive capacity of the species (Oliveira et al., 2016). Intraspecific genetic variability is fundamental for the persistence of species in nature, therefore knowing how much genetic variation exists and how it is distributed geographically in each species is necessary in order to characterize its conservation status (Santos et al., 2010). Thus, many studies have used genetic markers as a tool to map the variability and genetic distribution of species.

According to Turchetto-Zolet et al. (2017), a genetic marker is any visible character or phenotype that is somehow analyzable, by which alleles in individual loci segregate in a Mendelian manner. DNA molecular markers are effective tools for revealing the presence of genetic polymorphism, and are widely used in genetic studies of plant populations (Borém \& Caixeta, 2016; Cordeiro et al., 2020). Among them, those based on polymerase chain reaction (PCR) stand out since they can be applied to non-model species and can be classified according to the type of allelic inheritance in dominant and codominant markers (Turchetto-Zolet et al., 2017), and the dominant markers do not distinguish between dominant homozygotes and heterozygotes (Zietjiewicz et al., 1994; Costa et al., 2015). 
Among the dominant markers based on PCR are ISSR (Inter Simple Sequence Repeat), widely used in studies related to genetic characterization, due to low cost and high reproducibility ( $\mathrm{Ng} \& \mathrm{Tan}, 2015)$. Polymorphisms between individuals are identified in electrophoretic analyses by the presence or absence of amplicons.

Thus, the objective herein was to evaluate the diversity and genetic structure among individuals of Copaifera langsdorffii Desf. from Mato Grosso in the Brazilian Amazon, using ISSR markers.

\section{Methodology}

\subsection{Sampling}

We sampled the leaves of 27 adult individuals of C. langsdorffii found in the location known as Pista do Cabeça (S $10^{\circ}$ $23^{\prime} 22^{\prime \prime}$, W $56^{\circ} 24^{\prime} 27^{\prime}$ ), in the municipality of Alta Floresta, located in the north of the state of Mato Grosso (Figure 1), whose climate according to Alvares, Stape, Sentelhas, Gonçalves, and Sparovek (2013) is classified as AM type (tropical humid or subhumid). The average temperature is $24^{\circ} \mathrm{C}$ and precipitation is from 2800 to $3100 \mathrm{~mm}$. The collection points were geo-referenced with the aid of a GPS (Global System Position). The individuals were collected at points where there was already evidence of the existence of the species in question, with of a the help local resident. They are later grouped into four sample subunits according to their geographic proximity. Samples subunits: I (AF1, AF6, AF7 and AF8); II (AF2, AF3, AF4, AF5 and AF9); III (AF10, AF11, AF12, AF13, AF14, AF15, AF16, AF17, AF18 and AF19) and IV (AF20, AF21, AF22, AF23, AF24, AF25, AF26 and AF27) [Figure 1D]. Sample subunit IV is further away from the others, being $36 \mathrm{~km}$ from III, $41 \mathrm{~km}$ from I and 44 $\mathrm{km}$ from II. The closest subunits are I and III $(7 \mathrm{~km})$.

Figure 1. Location of individuals of Copaifera langsdorffii, collected in Alta Floresta, MT. The subunits are highlighted (I, II, III e IV).
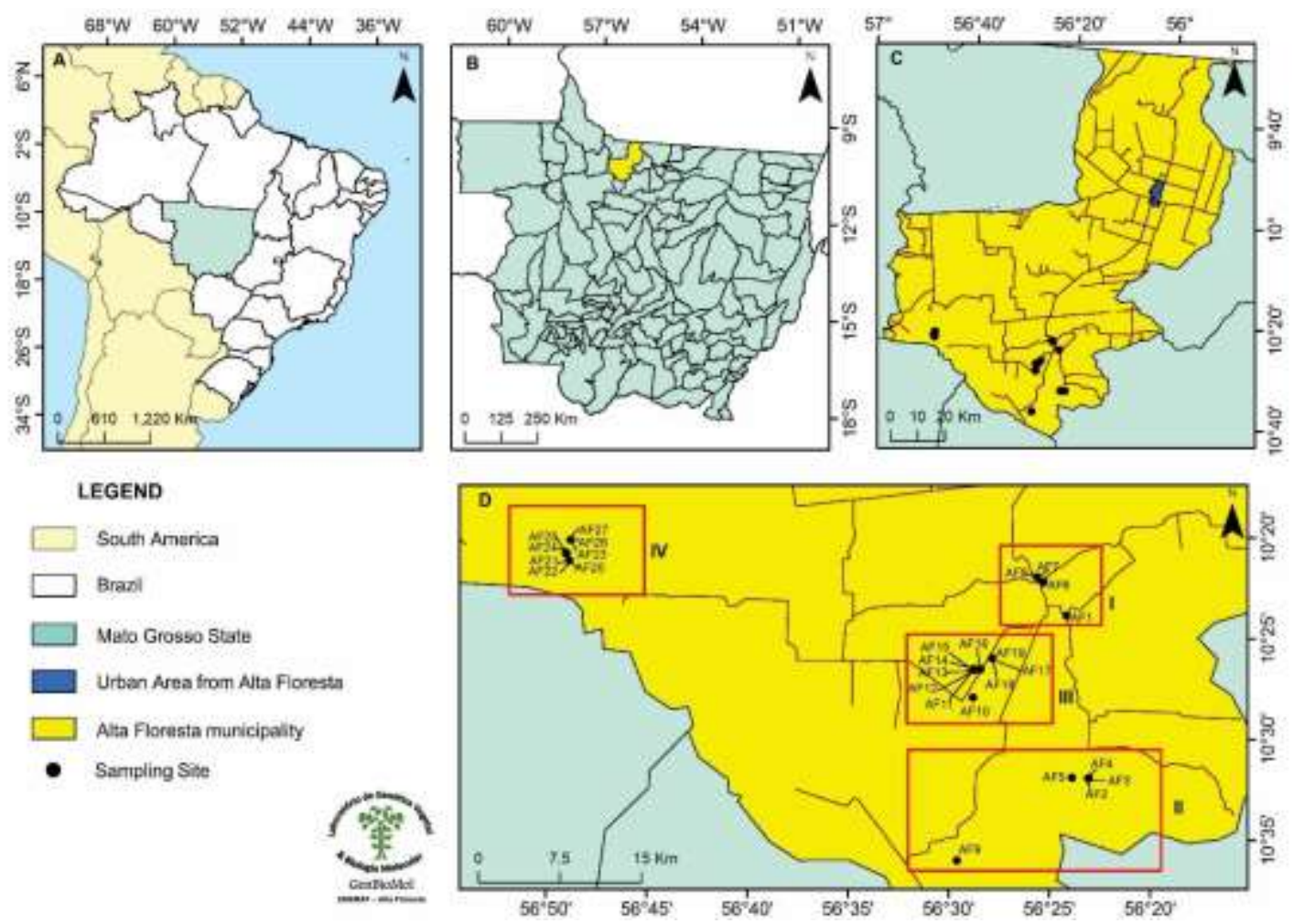

Source: Authors (2020). 


\subsection{DNA extraction and quantification}

The laboratory procedures were performed at the Laboratory of Genetics and Molecular Biology of the University of Mato Grosso Carlos Alberto Reyes Maldonado (UNEMAT) in Alta Floresta/Mato Grosso. Total genomic DNA was extracted from approximately $300 \mathrm{mg}$ of leaves from each sample, following the CTAB (cetyltrimethylammonium bromide) protocol described by Doyle and Doyle (1987). The evaluation of the quality of the extracted DNA, as well as the quantification, were performed using electrophoresis in $0.8 \%$ agarose gel $(\mathrm{m} / \mathrm{V})$ stained with ethidium bromide $(0.6 \mu \mathrm{g} / \mu \mathrm{L}-1)$ for 20 minutes. After quantification, the extracted DNA samples were diluted in autoclaved distilled water and standardized to a concentration of approximately $10 \mathrm{ng} \mu \mathrm{L}-1$.

\subsection{Amplification reactions}

A total of 12 ISSR primers [UBC -808 (DiAG3'C), UBC -810 (DiGA3'T), UBC -816 (DiCA3'T), UBC -817 (DiCA3'A), UBC - 818 (DiCA3'G), UBC - 825 (DiAC3’T), UBC - 828 (DiTG3'A), UBC - 829 (DiTG3’C), UBC - 834 (DiAG3'YT), UBC - 873 (GACA4), DiCA5'CR, DiCA5'CY] were used for the molecular characterization of individuals. The amplification reactions via PCR were performed in a total volume of $15 \mu \mathrm{L}$, which contained 20ng of DNA, $2.5 \mathrm{mM}$ of $\mathrm{MgCl} 2$, $0.2 \mathrm{mM}$ primer, $0.2 \mathrm{mM}$ of each $\mathrm{dNTP}, 2 \%$ of DMSO, $0.5 \mathrm{U}$ of Taq polymerase and IB10X buffer. The amplification cycles consisted of initial denaturation at $94{ }^{\circ} \mathrm{C}$ for 1.5 minutes, followed by 35 cycles of $94{ }^{\circ} \mathrm{C}$ for 45 seconds, specific annealing temperature of each primer for 45 seconds, $72{ }^{\circ} \mathrm{C}$ for 1.5 minutes and ended with a final extension of 5 minutes at $72{ }^{\circ} \mathrm{C}$, in a thermocycler. The amplification products were separated by electrophoresis in agarose gel 1.5\% in TBE 1X running buffer ( $89.15 \mathrm{mM}$ Tris Base, $88.95 \mathrm{mM}$ boric acid and $2.23 \mathrm{mM}$ EDTA), at a constant voltage of $90 \mathrm{~V}$ for four hours in a horizontal LCH 20x25 electrophoresis system. The sizes of the fragments obtained were compared with the molecular marker of $100 \mathrm{bp}$ DNA Ladder (KAPA, EUA).

\subsection{Statistical analysis}

The matrix of presence (1) and absence (0) of the amplicons was obtained from visual evaluation of the most defined fragments for each primer in the 27 subjects studied. Based on the matrix, the genetic similarities between the individuals of $C$. langsdorffii were determined using the Jaccard coefficient, and a grouping analysis was performed using the unweighted pair group method with arithmetic mean (UPGMA); the cutoff point was defined according to the methodology proposed by Mojena (1977). The bootstrap reliability index was also estimated based on 1000 repetitions, as well as the cophenetic correlation coefficient (r). The analyses were performed using the GENES program (Cruz, 2016). The Structure program (Pritchard et al., 2000), based on Bayesian analysis, was used to infer the structure of the population, which indicated distinct genetic groups (K) and assigned individuals to these groups. In all, 20 runs were performed for each $K$ value $(K=4), 200,000$ initial interactions (burn-ins) and 500,000 Markov chain Monte Carlo (MCMC) simulations. The criteria described by Pritchard and Wen (2004) and Evanno et al., (2005) were used to define the most likely $\mathrm{K}$ in relation to those proposed. To characterize the genetic variability between the genetic groups constituted by the Bayesian analysis, the genetic diversity of Nei (He) (Nei, 1978), the Shannon diversity index (I) (Lewontin, 1972) and the percentage of polymorphic loci (\%P) were calculated from the analysis of the binary matrix of presence and absence, using the program POPGENE 1.32 (Yeh et al., 2000). Genetic diversity among and within groups was demonstrated using AMOVA (analysis of molecular variance), according to Excoffier et al., (1992) and with the aid of the Arlequin 3.01 program (Excoffier et al., 2007). 


\section{Results}

The extracted DNA showed high quality. The 12 primers that were used amplified 106 fragments, and were $98.11 \%$ polymorphic. The number of amplified fragments ranged from 6 (UBC-828 and UBC-873) to 16 (UBC-810), with an average of 8.83 fragments per primer (Table 1). The polymorphic information content (PIC) of each primer ranged from 0.45 (UBC-816) to 0.81 (UBC-873).

Table 1. Total number of amplified fragments (TNF), number of polymorphic fragments (NPF), percentage of polymorphism $(\% \mathrm{P})$ and polymorphic information content (PIC) of primers used in the molecular characterization of Copaifera langsdorffii.

\begin{tabular}{ccccc}
\hline Primer & TNF & NPF & $\%$ P & PIC \\
\hline UBC-808 DiAG3'C & 9 & 9 & 100 & 0.66 \\
UBC-810 DiGA3'T & 16 & 16 & 100 & 0.73 \\
UBC-816 DiCA3'T & 7 & 6 & 85.71 & 0.45 \\
UBC-817 DiCA3'A & 10 & 10 & 100 & 0.69 \\
UBC-818 DiCA3'G & 9 & 9 & 100 & 0.79 \\
UBC-825 DiAC3'T & 8 & 7 & 87.5 & 0.71 \\
UBC-828 DiTG3'A & 6 & 6 & 100 & 0.68 \\
UBC-829 DiTG3'C & 12 & 12 & 100 & 0.72 \\
UBC-834 DiAG3'YT & 7 & 7 & 100 & 0.59 \\
UBC-873 GACA4 & 6 & 6 & 100 & 0.81 \\
DiCA5'CR & 9 & 9 & 100 & 0.56 \\
DiCA5'CY & 7 & 7 & 100 & 0.64 \\
\hline Total & 106 & 104 & 98.11 & - \\
Mean & 8.83 & 11.6 & 97.77 & 0.67 \\
\hline
\end{tabular}

The values of genetic dissimilarity observed among individuals ranged from 0.24 to 0.69 . The least genetically dissimilar individuals were AF20 and AF21, and AF24 and AF25, both pairs with 0.24, and all belonged to sample subunit IV. The most dissimilar were AF5 and AF27 with 0.69, and belonged to sample subunits II and IV respectively, as more distant from each other geographically, it may be a question of belonging to parents from other regions. Among the combinations, $41 \%$ are within the range $0.41-0.50$ (Figure 2). The mean dissimilarity found was 0.49 .

Figure 2. Distribution of genetic dissimilarity between pairs of individuals of Copaifera langsdorffii.

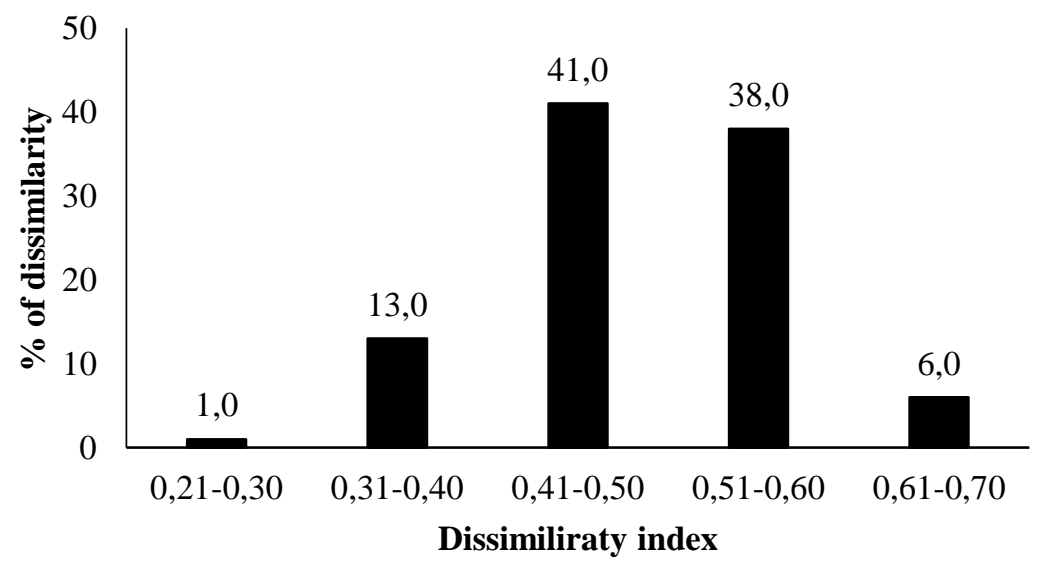

Source: Authors. 
Among the clustering methods tested, the UPGMA presented higher cophenetic correlation coefficient (CCC) (0.728), lower stress (10.39) and distortion (1.08). The genetic dissimilarity dendrogram based on the ISSR was generated by the UPGMA method, and based on the dissimilarity matrix, forming 4 groups (GI, GII, GIII, GIV) (Figure 3). Bayesian analysis demonstrated the existence of 2 distinct groups $(k=2)$ named A and B (Figure 4).

Figure 3. Dendrogram of genetic dissimilarity among the 27 individuals of Copaifera langsdorffii Desf., obtained using the UPGMA method and the arithmetic complement of the Jaccard index as a measure of dissimilarity. The markings correspond to the groups generated by the Structure program (see Figure 4). *individuals most distinct from the others within Group A in the Structure program analysis.

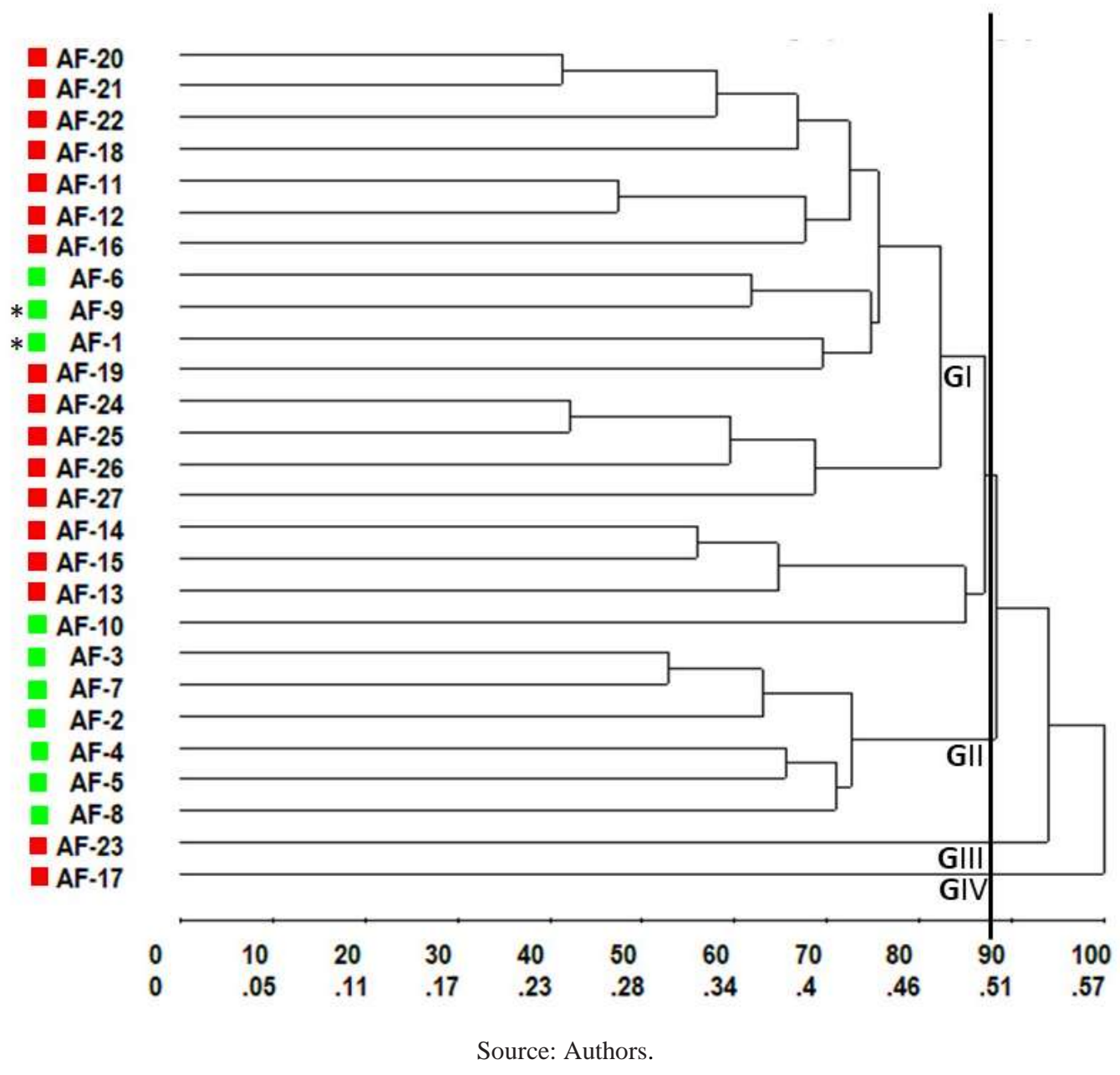


Figure 4. Grouping obtained using Bayesian analysis of the 27 individuals of Copaifera langsdorffii Desf. Individuals are represented by vertical bars with coloring according to the group to which they belong (two groups, $\mathrm{K}=2$ ). The light coloration represents the individuals of Group A, and the dark coloration represents the individuals belonging to Group B. * the most distinct individuals within Group A.

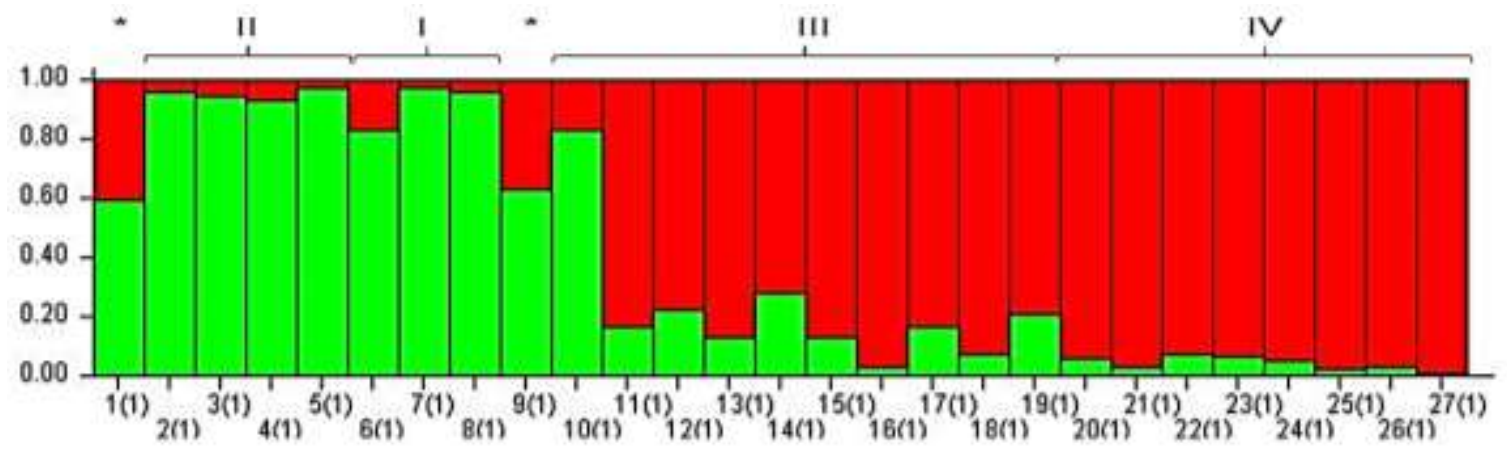

Source: Authors.

The indices of genetic diversity (Table 2) were calculated from the groupings $(\mathrm{k}=2)$ obtained in the Bayesian analysis. The percentage of polymorphism varied between 74.53 and $88.68 \%$, and the total percentage was $92.45 \%$, indicating high genetic diversity. Groups A and B of the Bayesian analysis presented a Shannon index (I) of 0.37 and 0.46 , respectively. The genetic diversity values of Nei were 0.24 and 0.31 for groups A and B, respectively.

The analysis of molecular variance (AMOVA), also based on the two groups obtained by Bayesian analysis, indicated that the greatest genetic variability is within each group ( $85.84 \%$ of total variance) and not between them. The group genetic differentiation value (FST) was 0.14162 , with 1023 random permutations, indicating that, between the groups, the variation is approximately $14 \%(\mathrm{p}<0.000)$.

Table 2. Intra-populational genetic diversity of Copaifera langsdorffii in groups A and B obtained using Bayesian analysis.

\begin{tabular}{cccc}
\hline Parameters & Group A & Group B & Total \\
\hline $\mathrm{N}$ & 10 & 17 & 27 \\
$\mathrm{Na}$ & $1.74( \pm 0.44)$ & $1.88( \pm 0.32)$ & $1.92( \pm 0.27)$ \\
$\mathrm{Ne}$ & $1.41( \pm 0.36)$ & $1.53( \pm 0.36)$ & $1.53( \pm 0.33)$ \\
$\mathrm{He}$ & $0.24( \pm 0.19)$ & $0.31( \pm 0.17)$ & $0.32( \pm 0.16)$ \\
$\mathrm{I}$ & $0.37( \pm 0.26)$ & $0.46( \pm 0.23)$ & $0.48( \pm 0.21)$ \\
$\% \mathrm{P}$ & 74.53 & 88.68 & 92.45 \\
\hline
\end{tabular}

$\mathrm{N}$ : number of individuals; Na: number of alleles observed; Ne: number of effective alleles; He: genetic diversity of Nei; I: Shannon index, and \%P: percentage of polymorphic loci. Source: Authors.

\section{Discussion}

The primers used herein were effective in the detection of genetic polymorphism of C. langsdorffii and there is genetic diversity among the individuals sampled. The high percentage of polymorphism (99.80\%) found in this study is similar to that found by Dúcar, Rewers, Jedrzejczyk, Mártonfi, and Sliwinska (2018), who evaluated the genetic diversity of eight species of Lotus sp. (Fabaceae), as well as that observed by Bagheri, Abbasi, Mahmoodi, Roofigar, and Blattner (2020) (97.60\%), who studied the genetic variability of Astragalus subrecognitus (Fabaceae), which demonstrates the effectiveness of ISSR markers in the detection of polymorphism in species of the Fabaceae family.

The polymorphic information content (PIC) demonstrated that 11 of the 12 primers used in this study can be considered as very informative for $C$. langsdorffii, since they presented PIC values above 0.5 . Only the primer UBC-816 showed a value 
between 0.25 and 0.50, which makes it moderately informative. For Botstein, White, and Davis (1980), molecular markers that present PIC values below 0.25 are considered to be poorly informative, whereas those with values between 0.25 and 0.50 are classified as moderately informative and above 0.50 are very informative.

The mean dissimilarity found was similar to that found by Brito et al. (2016) for the species Varronia curassavica, which, according to the authors, indicates a high genetic diversity among many pairs of individuals. Dissimilarity data indicate that there is no evidence of genetically identical individuals, and these therefore present potential for the composition of germplasm banks. The CCC value obtained in the UPGMA is considered satisfactory according to Rohlf (1970), since it is above 0.70 , and indicates a good adjustment between the dissimilarity matrix and the cophenetic matrix.

Considering the results obtained by UPGMA and Bayesian analysis, the disposition of individuals from different sample subunits in the same genetic grouping can be explained by the fact that their main dispersers are birds (Rabello, Ramos, \& Hasui, 2010), and this type of dispersion allows dispersion over long distances. According to Trolliet, Forget, Doucet, Gillet, and Hambuckers (2017) and Oliveira et al. (2020), this plant-frugivore relationship has a fundamental role in the forest structure, and may be one of the main mechanisms of dispersal of plant species.

High genetic diversity in Copaifera langsdorffii was also observed by Martins, Santos, Gaiotto, Moreno, and Kageyama (2008) who studied populations in Pontal do Paranapanema, in the state of São Paulo, using the analysis of microsatellite markers, as well as by Sebbenn et al. (2010), who evaluated a population of C. langsdorffii in the municipality of São Jose do Rio Preto, State of São Paulo. Indicating that even with the pressure exerted by exploration and deforestation, individuals with high genetic diversity can still be found that demonstrate the capacity to be used in the conservation of the species.

The Shannon index (I) resembled that found by Guerra, Gómez, Gutierrez, and Hahn (2018) (between 0.36 and 0.39 ) who evaluated genetic diversity in Adesmia bijuga Phil using ISSR markers. Group B has the highest genetic diversity, as well as the highest values for the Shannon and Nei indices, which may be associated with the geographical distance between the individuals, since this group is basically composed of the individuals sampled in subunits III and IV. AMOVA indicated that the greatest genetic variability is within each group, and allows a greater number of combinations between individuals, which, according to Demartelaere et al. (2020), is important for determine possible adaptations in the face of environmental changes. Nybom (2004) found, while analyzing studies performed with dominant markers, that long-lived, allogamous and latesuccessional plants presented greater genetic variability within populations, which is in accordance with the characteristics and lifestyle of Copaifera langsdorffii.

Given the scenario of forest degradation in Brazil, the genetic diversity found among individuals of Copaifera langsdorffii corroborate the importance of forest preservation and conservation, since, according to Fonseca et al. (2021), the area deforested in the 2021 deforestation calendar (August 2020 and July 2021) was $10476 \mathrm{~km}^{2}, 57 \%$ larger than that recorded in the previous year. The possible creation of ecological corridors between the fragments to connect them or bring them closer together would make the gene flow more viable. Martins et al. (2008) state that the connectivity between fragments facilitates the maintenance of genetic diversity and allows the movement of fauna, enabling the dispersal of seeds of zoochoric species (Trolliet et al., 2017; Oliveira et al., 2020).

\section{Conclusion}

The results herein indicate that the evaluated individuals of $C$. langsdorffii have high genetic diversity, and thus have potential to compose programs aimed at the preservation and conservation of the species and may be integrated in germplasm banks. They also evidenced the efficiency of the DNA extraction and amplification method using the ISSR markers described in this work, confirming the possibility of applying these for the genetic study with other populations the species. 


\section{Acknowledgments}

This study was financed in part by the Coordenação de Aperfeiçoamento de Pessoal de Nível Superior Brasil (CAPES) - Finance Code 001.

\section{References}

Alvares, C. A., Stape, J. L., Sentelhas, P. C., Gonçalves, J. L. M., \& Sparovek, G. A. (2013). Koppen's climate classification map for Brazil. Meteorologische Zeitschrift, 22(6), 711-728.

Bagheri, A., Abbasi, S., Mahmoodi, M., Roofigar, A. A., \& Blattner F. R. (2020). Genetic structure and conservation status of Astragalus subrecognitus (Fabaceae): a very rare and narrow endemic species Plant. Ecology and Evolution, 153(1), 101-107.

Borém, A., \& Caixeta, E. T. (2016). Marcadores moleculares (3a ed). UFV.

Botstein, D., White, R. L., \& Davis, R. W. (1980). Construction of a genetic linkage map in man using restriction fragment length polymorphisms. American Journal of Human Genetics, 32(3), 314-331.

Brito, F. A., Nizio, D. A. C., Silva, A. V. C., Diniz, L. E. C., Rabbani, A. R. C., Arrigoni-Blank, M. F. \& Blank, A. F. (2016). Genetic diversity analysis of Varronia curassavica Jacq. Accessions using ISSR markers. Genetics and Molecular Research, 15(3), 1-10.

Cordeiro, A. G. M., Silva, L. H. R., Cardoso, E. S., Pena, G. F., Zortéa, É. M., \& Rossi, A. A. B. (2020). Diversidade genética entre cupuízeiros nativos do Portal da Amazônia, Mato Grosso, Brasil. Scientific Electronic Archives, 13(3), 51-56.

Costa, D. F., Vieira, F. A., Farjado, C. G., \& Chagas, K. P. T. (2015). Diversidade genética e seleção de iniciadores ISSR em uma população natural de mangaba (Hancornia especiosa Gomes) (Apocenaceae). Revista Brasileira de Fruticultura, 37(4), 970-976.

Cruz, C. D. (2016). Genes Software - extended and integrated with the R, Matlab and Selegen. Acta Scientiarum, 38(4), 547-552.

Demartelaere, A. C. F., Nascimento, L. C., Preston, H. A. F., Silva, H. F., Silva, E. C., Preston, W. \& Souza, J. B. (2020). Aspectos morfofisiológicos, variabilidade genética e controle alternativo da Alternaria alternata f. sp. citri em tangerineira 'Dancy'. Brazilian Journal of Development, 6(11), 90621-90646.

Doyle, J. J., \& Doyle, J. L. (1987). A rapid DNA isolation procedure for small quantities of fresh leaf tissue. Phytochemical bulletin, 19 , 1115.

Dúcar, E., Rewers, M., Jedrzejczyk, I., Mártonfi, P., \& Sliwinska, E. (2018). Comparison of the genome size, endoreduplication, and ISSR marker polymorphism in eight Lotus (Fabaceae) species. Turkish Journal of Botany, 42, 1-14.

Evanno, G., Regnaut, S., \& Goudet, J. (2005). Detecting the number of clusters of individuals using the software Structure: a simulation study. Molecular Biology, 14, 2611-2620.

Excoffier, L., Smouse, P. E., \& Quattro, J. M. (1992). Analysis of molecular variance inferred from metric distances among DNA haplotypes: application to human mitochondrial DNA restriction data. Genetics, 131(2), 179-191.

Excoffier, L., Laval, G., \& Schneider, S. (2007). Arlequin: a software for population data analysis. Version 3.1. University of Geneva.

Ferreira, M., Barroso, M., Valdujo, P., \& Costa, G. (2010). Arpa: Biodiversidade. Ministério do Meio Ambiente, Brasil: Autor.

Fonseca, A., Amorim, L., Ribeiro, J., Ferreira, R., Monteiro, A., Santos, B. \& Veríssimo, A. (2021). Boletim do desmatamento da Amazônia Legal (julho 2021) SAD (p. 1). Belém: Imazon

Guerra, F. P., Gómez, P., Gutierrez, A., \& Hahn, S. (2018). Diversidade genética de Adesmia bijuga Phil., uma espécie de Fabaceae ameaçada de extinção do Chile Central. Revista Brasileira de Botânica, 41(1), 247-251.

Lewontin, R. C. (1972). The Apportionment of Human Diversity Committee on Evolutionary Biology. University of Chicago, 381-398.

Lisboa A. J. M., Queiroz F. J. G., Giotto A. C., Santos J. F., \& Silva, K. C. (2018). Análises fotoquímicas de Copaifera langsdorffii Desf. Revista Científica Sena Aires, 7(3), 208-13.

Lorenzi, H. (1992). Árvores brasileiras: manual de identificação e cultivo de plantas arbóreas nativas do Brasil (p.352). Plantarum.

Martins, K., Santos, J. D., Gaiotto, F. A., Moreno, M. A., \& Kageyama, P. Y. (2008). Estrutura genética populacional de Copaifera langsdorffii Desf. (Leguminaseae - Caesalpinioideae) em fragmentos florestais no portal do Paranapanema, SP, Brasil. Revista Brasileira de Botânica, 31(1).

Mojena R. (1977). Hierarchical grouping methods and stopping rules: an evaluation. The Computer Journal, $20(4), 359-363$.

Nei, M. (1978). Estimation of average heterozygosity and genetic distance from a small number of individuals. Genetics, 89, 583-590.

Ng, W. L., \& Tan, S. G. (2015). Inter-Simple Sequence Repeat (ISSR) markers: Are we doing it right? ASM Science Journal, 9(1), 30-39.

Nybom, H. (2004). Comparison of different nuclear DNA markers for estimating intraspecific genetic diversity in plants. Molecular Ecology, 13 , $1143-1155$.

Oliveira, R. A., Silva, D. C. C., Simonettii, V. C., Stroka, E. A. B., \& Sabonaro, D. Z. (2016). Proposição de Corredor Ecológico entre duas Unidades de Conservação na Região Metropolitana de Sorocaba. Revista do Departamento de Geografia, 32, 61-71. 
Research, Society and Development, v. 10, n. 16, e187101623025, 2021 (CC BY 4.0) | ISSN 2525-3409 | DOI: http://dx.doi.org/10.33448/rsd-v10i16.23025

Oliveira, A. T. M., Canale, G. R., Nogueira, L. A. S., França, A. L., Santos, J. P., \& Córdova, M. O. (2020). Estrutura e síndromes de dispersão da vegetação arbórea em floresta nativa e agrofloresta, na Amazônia meridional. Revista de Ciências Agrárias, 43(3), 352-362.

Pritchard, J., Stephens, M., \& Donnelly, P. (2000). Inference of population structure using multilocus genotype data. Genetics, 155, 945-959.

Pritchard, J. K., \& Wen, W. (2004). Documentation for Structure software: Version 2.1.

Rabello, A., Ramos, F. N., \& Hasui, É. (2010). Efeito do tamanho do fragmento na dispersão de sementes de Copaíba (Copaifera langsdorffii Delf.). Biota Neotropica, 10(1), 47-54.

Reis, S. M., Marimon-Júnior, B. H., Morandi, P. S., Oliveira-Santos, C., Oliveira, B., \& Marimon, B. S. (2016). Desenvolvimento inicial e qualidade de mudas de Copaifera langsdorffii Desf. sob diferentes níveis de sombreamento. Revista Ciência Florestal, 26(1), 11-20.

Rohlf, F.J. (1970). Adaptative hierarchical clustering schemes. Systematic Zoology, 19(1), 58-82.

Santos, F. R., Lacerda, D. R., Redondo, R. A. F., Nascimento, A. M. A., Chartone-Souza, E., Borba, E. L. \& Lovato, M. B. (2010). Diversidade genética. Biota Minas, 389-410.

Sebbenn, A. M., Carvalho, A. C. M., Freitas, M. L. M., Moraes, S. M. B., Gaino, A. P. S. C., Silva, J. M. \& Moraes, M. L. T. (2011). Baixos níveis de fluxo gênico de sementes e pólen realizados e forte estrutura genética espacial em uma população pequena, isolada e fragmentada da árvore tropical Copaifera langsdorffii Desf. Heredity, 106, 134-145.

Silva, R.B.C. (2018). Importância da biodiversidade. In: Martins, M. B.; Jardim, M. A.G. Reflexões em biologia da conservação. Museu Paraense Emilio Goeldi, $1,19-25$.

Sousa, K. A., Santoyo, A. H., Rocha, W. F., Jr., Matos, M. R. de, \& Silva, A. de C. (2016). Bioeconomia na Amazônia: uma análise dos segmentos de fitoterápicos \& fitocosméticos, sob a perspectiva da inovação. Fronteiras: Journal of Social, Technological and Environmental Science, 5(3), 151-171.

Trolliet, F., Forget, P. M., Doucet, J. L., Gillet, J. F., \& Hambuckers, A. (2017). Aves frugívoras influenciam a organização espacial das florestas tropicais através da geração de focos de recrutamento de mudas sob ambiente zoocórico. Acta Oecologica, 85, 69-76.

Turchetto-Zolet, A. C., Turchetto, C., Zanella, C. M., \& Passia, G. (2017). Marcadores moleculares na era genômica: metodologias e aplicações. Ribeirão Preto: Sociedade Brasileira de Genética, 12-20.

Veiga, V. F., Jr., \& Pinto, A. C. O Gênero Copaifera L. Química Nova, 25(2), p. 273-286, 2002. DOI: https://doi.org/10.1590/S0100-40422002000200016

Yeh, E., Yang, C., Chin, E., Maddox, P., Salmon, E. D., Lew, D. J. \& Bloom, K. (2000). Dynamic positioning of mitotic spindles in yeast: role of microtubule motors and cortical determinants. Molecular Biology of the Cell, 11, 3949-3961.

Zietjiewicz, E., Rafalski, A., \& Labuda, D. (1994). Genome fingerprinting by simple sequence repeat (SSR)-anchored polymerase chain reaction amplifcation. Genomics, 20, 176-183. 